\title{
USE OF FLOW CYTOMETRY FOR PRODUCING TETRAPLOIDS IN RED CLOVER
}

\author{
Aija Rebāne ${ }^{1, \#}$, Dace Grauda ${ }^{2}$, Sarmìte Rancāne ${ }^{1}$, Aldis Jansons $^{1}$, and Isaak Rashal ${ }^{2}$ \\ ${ }^{1}$ Research Institute of Agriculture, Latvia University of Life Sciences and Technologies, Skriveri, LV-5125, LATVIA \\ 2 Institute of Biology, University of Latvia, 3 Miera Street, Salaspils, LV-2169, LATVIA \\ \# Corresponding author, aijarebane@inbox.Iv
}

Contributed by Isaak Rashal

\begin{abstract}
Sprouts of diploid red clover 'Stendes Agrais' were treated with $0.2 \%$ colchicine solution. The ploidy level of plants was detected by flow cytometry. Most of the treated plants were mixoploids and sterile. From progenies of fertile plants, mixoploids were selected that had a proportion of tetraploid cells higher than $60 \%$. In the next generation, stable tetraploid plants were selected, and 49 lines were included in the breeding process.
\end{abstract}

Key words: Trifolium pratense, mixoploidy, breeding.

Red clover (Trifolium pratense L.) is a plant used as a multipurpose crop, mainly as forage. Creation of polyploid varieties is a perspective direction in red clover breeding — it is well known, that polyploids usually have higher vegetative mass (Sattler et al., 2015) and hence higher forage yield is expected. In breeding of polyploid varieties it is important to choose appropriate initial material, which usually are diploid varieties adapted to the local conditions. As spontaneous polyploidy is a rather rare event, intensive breeding programmes cannot be based on this approach. An alternative is induced polyploidy in specially selected diploid material. Several chemical compounds that can destroy microtubules during cell division in mitosis can be used as inducing agents. Since the 1930s, colchicine, a natural agent extracted from the wild plant Colchicinum vulgare, has been widely used for this purpose (Eigsti, 1938). Nowadays several new synthetic compounds are also successfully used as polyploidy inducing agents (see, for example, Melnychuk et al., 2020).

The aim of our work was to explore the possibility of using flow cytometry as an approach in creating tetraploid red clover lines for practical breeding. The initial material for creating polyploids was diploid red clover variety 'Stendes Agrais' (Latvia), which was developed by the prominent Latvian breeder Jānis Lielmanis already in the 1950s (Belicka and Kalmanis, 2012) and is well suited for Latvian agro-climatic conditions. Polypoidisation was performed by colchicine treatment of sprouts. Clover seeds were sterilised using an earlier developed approach (Ornicane and Rashal, 1997). Approximately $1 \mathrm{~g}$ of seeds was washed in soap water solution with $100 \mu \mathrm{l} / \mathrm{l}$ Tween 40 for 10 minutes, subsequently washed under running water, then placed in $0.015 \%$ $\mathrm{KMnO}_{4}$ solution for 40 minutes and after that washed with distilled water 4-5 times until water lost its pink colour. Then seeds were treated with $50 \%$ solution of the commercial bleach Belizna for 17 minutes. After that seeds were rinsed in deionised water four times. Sterilised seeds were transferred to Petri dishes with $1 / 2$ Murashige \& Skoog (1962) medium (agar $7 \mathrm{~g} / \mathrm{l}, \mathrm{pH}$ 6.0). The best results were achieved when seeds were placed in several groups of 10-15 seeds (Fig. 1A).

After 3-4 days of cultivation, sprouts of emerged seeds with two cotyledons were selected for colchicinisation (Fig. 1B). Optimal length of sprouts was $1.0-1.5 \mathrm{~cm}$ : sprouts shorter than $1 \mathrm{~cm}$ were not viable after colchicinisation. On sprouts longer than $1.5 \mathrm{~cm}$, calli very often were formed; such plantlets had low rooting ability, and as a result most of them died during the first week after transferring them to soil. Petri plates with selected sprouts were placed in a refrigerator with $+4{ }^{\circ} \mathrm{C}$ temperature for 8 hours, and then kept in daylight at temperature $24{ }^{\circ} \mathrm{C}$ for 2 hours. Then sprouts were transferred into Petri plates with $0.2 \%$ colchicine solution in such a way that the growth point was immersed in the solution (Fig. 1C) for 5 hours. After that, sprouts were 


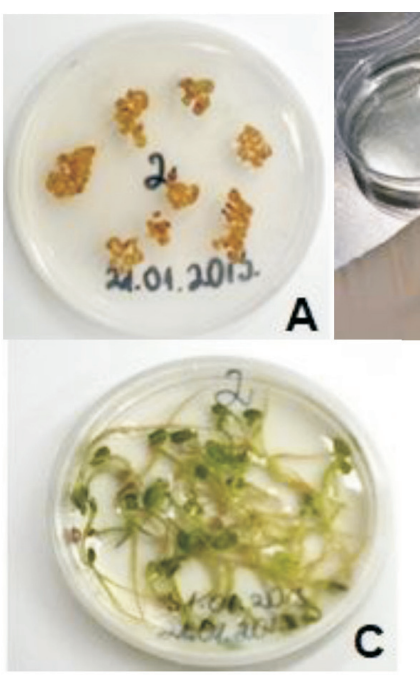

Fig. 1. Stages of colchinisation. A, red clover seeds placed on medium; $\mathrm{B}$, selection of sprouts with two cotyledons for colchicinisation; $\mathrm{C}$, plantlets in colchicine solution.

rinsed four times with sterile water and placed in Petri dishes on L2 culture medium (Phillips, 1996) and placed in a cultivation chamber "Termaks" at $20{ }^{\circ} \mathrm{C}$ with $16 \mathrm{~h}$ day (3000 lux) and $8 \mathrm{~h}$ night conditions.

Plants with well-developed leaves and roots were planted into $100 \mathrm{ml}$ pots with soil substrate (1 field soil: 1 neutralised peat substrate) and were cultivated in a greenhouse under partially controlled conditions (temperature, humidity).
After 3-4 weeks of cultivation, plants with a welldeveloped root system and 3-4 leafs were selected for ploidity determination.

Ploidity of plants was detected using a BD FACSJazz cell sorter with a flow cytometer function. Approximately $50-100 \mathrm{mg}$ of leaves were crushed in $500 \mu \mathrm{l}$ lysation buffer. After destruction of leaves, additional $1000 \mu$ of lysation buffer was added and kept at room temperature for 5 minutes. This solution was filled into flow cytometer tubes with addition of $40 \mu \mathrm{l}$ propodeum iodide Staining Solution (DB Bioscience, USA) and kept in darkness for 1 hour. A Partec kit (CyStain Ploidy, Germany) was used for cell nucleus isolation before fluorescent staining. Leaves of 'Stendes Agrais' were used a control diploid (Fig. 2).

Ploidy was determined for 120 plants, which were obtained after colchicinisation. Most of them were mixoploids with diploid, triploid and tetraploid cells (Figs. 3 and 4). Plants were moved into soil at open field conditions and grown till maturity. Most plants were sterile, seeds were collected only from 30 phenotypically polyploid (increased size) plants. They progenies were tested again for polyploidy level by the method described above. Among them, 13 plants $(6 \%)$ were diploid, 21 plants $(10 \%)$ were triploid and 176 plants $(84 \%)$ were mixoploids with different propor-

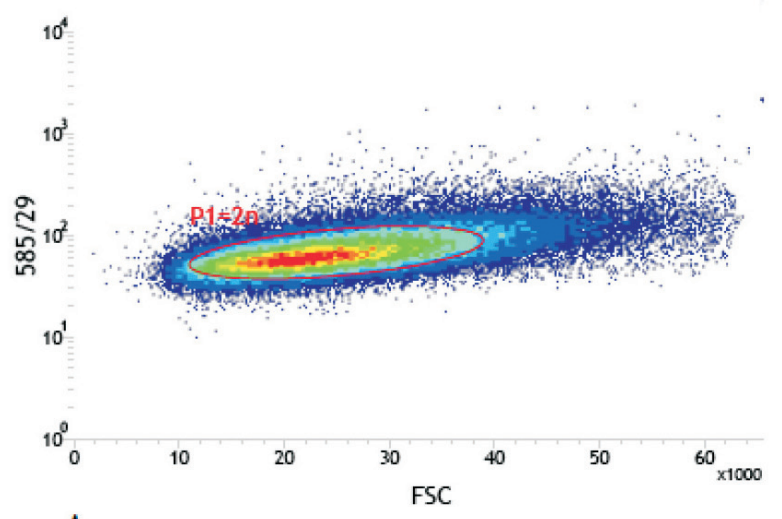

A

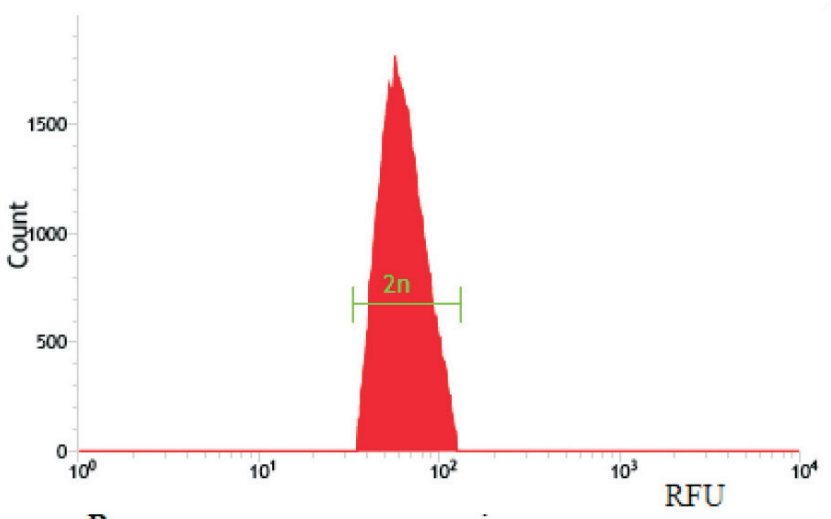

B

Fig. 2. Fluorescence of leaf cell's nucleus of diploid red clover plants in real time detection system 585/29 forward side scatter (A) and relative cell fluorescence (RFU) in log scale (B).

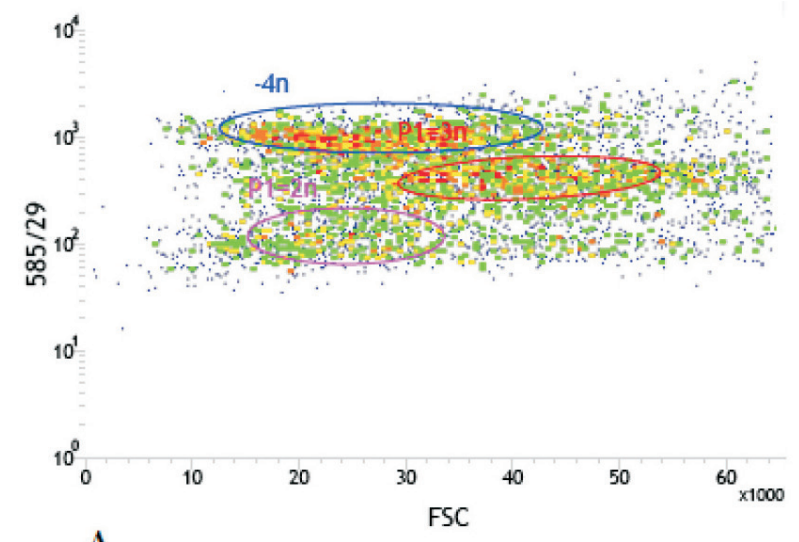

A

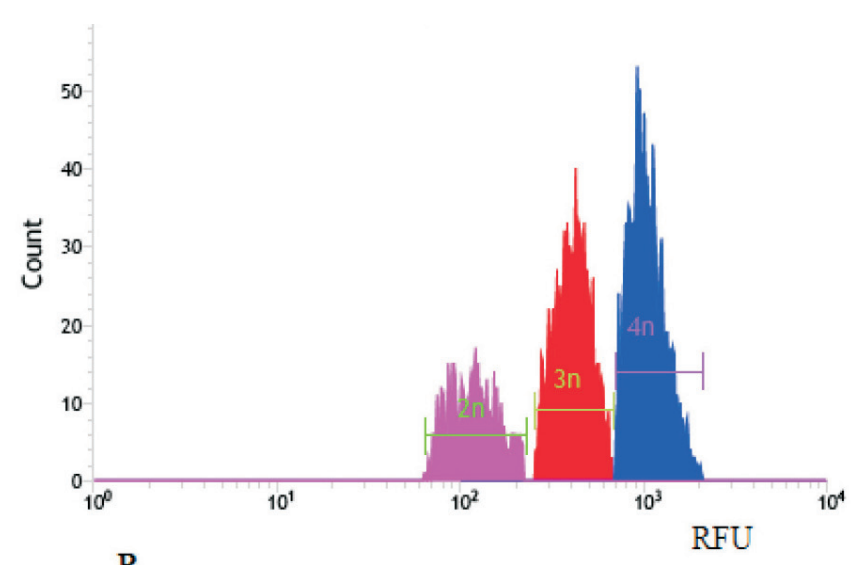

B

Fig. 3. Fluorescence of leaf cell's nucleus of red clover plants three weeks after colchicine treatment in real time detection system $585 / 29$ forward side scatter (A) and relative cell fluorescence (RFU) in log scale (B). 


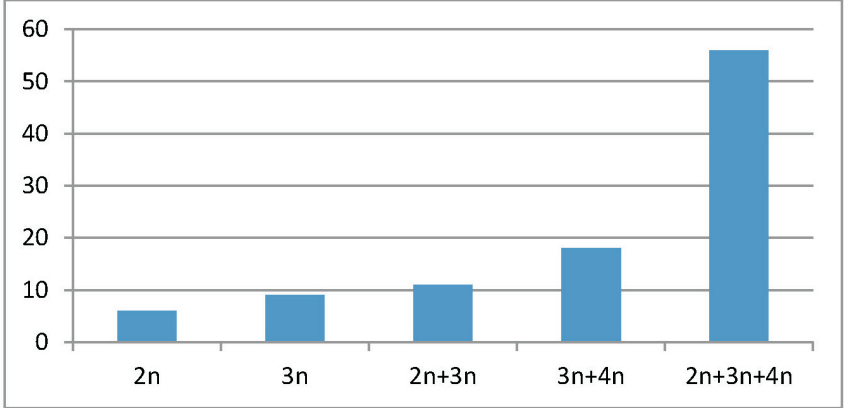

Fig. 4. Segregation of colchicined plants by mixoploidy.

tions of tetraploid cells. Plants with a proportion of tetraploids cells higher than $60 \%$ were selected for further propagation. From them, in the next generation 49 stable tetraploid lines were selected and included in the breeding process.

\section{CONCLUSION}

After colchicinisation of sprouts, most of the red clover plants were mixoploids with different proportions of diploid, triploid and tetraploid cells. Use of flow cytometry allowed to select mixoploids with a higher proportion of tetraploids cells, which led to creating stable tetraploid lines useful to include in breeding programmes.

\section{ACKNOWLEDGMENTS}

The research was supported by the Latvian Ministry of Agriculture within the Crop Breeding Programme in subprogramme "Investigation of breeding material of perennial grasses to implement integrated technologies in crops".

\section{REFERENCES}

Belicka I., Kalmanis Z. (2012). Contribution of Jānis Lielmanis in plant breeding in Latvia. Proc. Latvian Acad. Sci., Section B, 66 (1/2), 79-85.

Eigsti, O. J. (1938). A cytological study of colchicine effects in the induction of polyploidy in plants. Proc. Nat. Acad. Sci.USA, 24 (2), 56-63.

Melnychuk, O. V., Ozheredov, S., Rakhmetov, D. B., Shysha, O. O., Rakhmetova, S. O., Yemets, A. I., Blume Ya. B. (2020). Induction of polyploidy in giant miscanthus (Miscanthus $\times$ giganteus Greef et Deu.). Proc. Latvian Acad. Sci., Section B, 74 (3), 206-216.

Murashige, T., Skoog, F. (1962). A revised medium for rapid growth and bioassays with tobacco tissue culture. Physiol. Plantar., 15, 473-497.

Ornicāne, D., Rashal, I. (1997). Callus initiation from mature barley embryos and growth: Influence of silver nitrate and of the method of sterilization. Proc. Latvian Acad. Sci., Section B, 51 (1/2), 72-74.

Phillips, G. (1996). Tissue culture. In: Red Clover Science. Taylor, N. L., Quesenberry, K. H. (eds.). Kluwer Academic Publishers, Dordrecht, pp. $170-187$.

Sattler, M. C., Carvalho, C. R., Clarindo W. R. (2015). The polyploidy and its key role in plant breeding. Planta, 243 (2), 281-296.

\section{PLŪSMAS CITOMETRIJAS IZMANTOŠANA SARKANĀ ĀBOLIN̦A TETRAPLOĪDU IZVEIDOŠANAI}

Diploīdus šḳirnes ‘Stendes Agrais’ dīgstus apstrādāja ar 0,2\% kolhicīna šķīdumu lai iegūtu tetraploīdus augus selekcijas vajadzībām. Augu ploiditāti noteica ar plūsmas citometriju. Lielākā dạ̦a kolhicinēto augu bija miksoplō̄di un sterili. No fertilo augu pēcnācējiem atlasīja miksoploīdos augus, kuros tetraploīdo šūnu proporcija bija augstāka par $60 \%$. Nākamajā paaudzē iegūti stabili tetraploīdi, rezultātā 49 līnijas iekḷautas selekcijas procesā. 